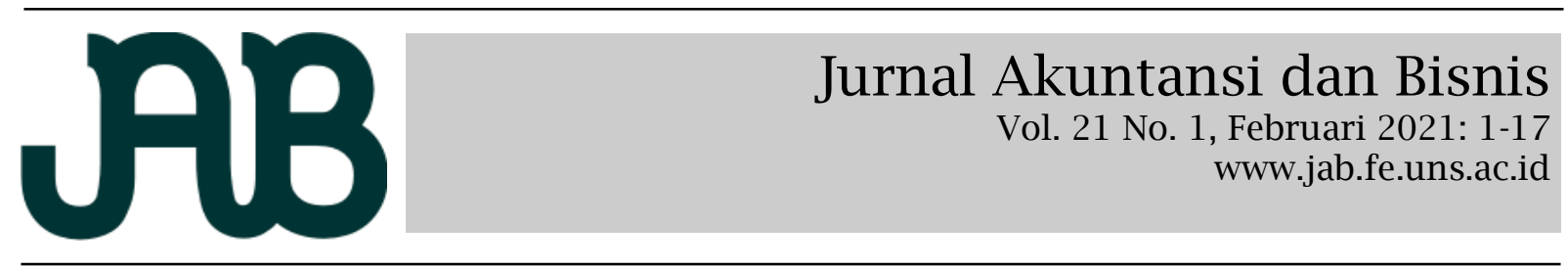

\title{
FACTORS INFLUENCING EARNINGS MANAGEMENT IN RAILWAY COMPANIES IN ASIA PACIFIC REGION
}

\author{
MEINA ROMADANI ${ }^{1}$ (61615@kai.id) \\ Y. ANNI ARYANI ${ }^{2}$
}

1 Master of Accounting Program, Faculty of Economics and Business, Universitas Sebelas Maret, Indonesia and PT Kereta Api Indonesia (Persero)

2 Master of Accounting Program, Faculty of Economics and Business, Universitas Sebelas Maret, Indonesia

\begin{abstract}
A B S T R A C T
This study focuses on the factors that affect earning management in railway companies throughout the Asia Pacific, especially bonus plans, leverage, and government subsidies. These three factors are closely related to the characteristics possessed by the railway company. This research is quantitative using secondary data from the annual financial reports of railway companies in the Asia Pacific region from 20102019 with a sample size of 171 financial reports. The sampling technique was car ried out using the purposive sampling method. Modified Jones Model is used to measure earnings management. To test the hypothesis in this study using panel data regression analysis using the E-views 9 program. The results showed that the bonus plan does not affect earning management. Leverage and government subsidies have a positive effect on earning management.

Keywords: railway, earning management, bonus plan, leverage, and government subsidy

Penelitian ini berfokus pada faktor-faktor yang mempengaruhi manajemen laba pada perusahaan perkeretaapian di seluruh Asia Pasifik, terutama bonus plan, leverage, dan subsidi pemerintah. Ketiga faktor tersebut erat kaitannya dengan karakteristik yang dimiliki oleh perusahaan perkeretaapian. Penelitian ini bersifat kuantitatif dengan menggunakan data sekunder berupa laporan keuangan tahunan perusahaan perkeretaapian di kawasan Asia Pasifik periode 2010-2019 dengan jumlah sampel 171 laporan keuangan. Teknik pengambilan sampel dilakukan dengan menggunakan metode purposive sampling. Modified Jones Model digunakan untuk mengukur manajemen laba. Untuk menguji hipotesis dalam penelitian ini menggunakan analisis regresi data panel menggunakan program E-views 9. Hasil penelitian menunjukkan bahwa rencana bonus tidak mempengaruhi manajemen laba. Leverage dan subsidi pemerintah berpengaruh positif terhadap manajemen laba

Kata kunci: perkeretaapian, manajemen laba, rencana bonus, leverage, dan subsidi pemerintah
\end{abstract}

\section{INTRODUCTION}

This study examines the phenomenon of earning management that occurs in railway companies. Although it is not a new topic in the literature, earning management is still interesting to be studied (Lisboa, 2016). Soliman (2019), states that earnings management aims to manipulate the financial report, preventing other parties to find out the company's actual financial condition. As companies desire to meet their stakeholders' expectation, earnings management behavior potential exist (Al-Absy,
Ismail \& Chandren, 2018).

Earnings management may decline the quality of a financial report since it does not represent the company's actual condition, potentially misleading the report users' decision-making process. Since an excessive practice of earnings management may lead to deception practice (Naidu \& Patel, 2013), companies should be aware that they need to stay within the regulated limit to prevent fraud scandals like Enron and WorldCom (the U.S.), Tesco (the U.K.), Biovail (Canada), One.Tel (Australia), and 
Olympus (Japan) from happening again in the future (Muda, Maulana, Sakti \& Indra, 2018).

The phenomenon of earnings management was introduced by Healy (1985), who examined the effect of bonus schemes on firms' decisions to undertake earning management. Since then, many researchers are interested in studying earnings management more deeply. Singh, Aggarwal \& Anand (2017), Ilyas, Ahmad, Khan \& Khan (2018), and Abdullah, Maruhun \& Ahmad (2018) researched earning management that focused on corporate governance. Obigbemi, Omolehinwa, Mukoro, Ben-Caleb \& Olusanmi (2016) and Lassoued, Attia \& Sassi (2017) researched earning management that focused on ownership structure. Lopes (2018) and Yasser and Soliman (2018) conducted earning management research focused on audit quality. Lemma, Negash \& Mlilo (2013), Azzali \& Mazza (2018), Lazzem \& Jilani (2018), Zhao, Zhou \& Zhao (2019), and Soliman (2019) conducted earning management research that focused on the incentives that could be obtained from earning management actions .

We are interested in associating the earnings management phenomenon with the positive accounting theory introduced by Watts \& Zimmerman (1978). This theory comprises three hypotheses, bonus plan, debt covenant, and political cost hypotheses (Watts \& Zimmerman, 1978). These three hypotheses are closely associated with a railway company's characteristics .

Compared to other companies, the railway company is unique due to several factors. First, this company employs a large number of employees. Based on the study conducted by Pereira (2015), Indian Railways, one of the Indian rail companies, is a rail company with the largest number of employees in the world with 1.7 million employees consisting of 1.4 million permanent employees and three hundred thousand non-permanent employees (Indian Railway Budget, 2008/2009, 2009/2010). The salary and benefit of permanent employees in Indian Railway take up to $45 \%$ of its operating cost (Pereira, 2015). The company's large number of employees can be used to consider company management to determine the bonus plan given to employees. Bonuses could be given in the form of bonus compensation for employees (Anggraeni \& Widyaningsih, 2020). Company management who desires a high bonus tends to engage in earnings management behaviors by increasing the company profit to make the company's performance looks satisfying (Watts \& Zimmerman, 1978). Consequently, the financial report of such a company does not represent the actual condition and mislead the users' decisionmaking process (Alhadab, 2018; Anwar \& Gunawan, 2020; Arianti \& Wijayanto, 2019; Harakeh, El-Gammal \& Matar, 2019; Panjaitan \& Muslih, 2019; Simanjuntak \& Anugerah, 2018; Widowati, 2013; Yustiningarti \& Asyik, 2017; Zubaidah \& Anwar, 2019).

Second, most of the railway companies have huge debt. Railway transportation is mass transportation with many advantages compared to other transportation modes (Sriastuti, 2015). Railway companies are considered to have a pivotal role in a country's economic development. The government often involves a railway company to support the state's economic development by assigning mandatory projects (Sudibya, 2007). Such projects often become the companies' financial burden. Accordingly, railway companies usually apply the combination of debt and share capital (Lawrence \& Ollivier, 2014). The debt could be a loan from the financial institution or an obligation sold to the community. According to Lawrence \& Ollivier (2014), rail companies prefer debt to fund their project than selling their share since they can have a smaller risk by using their rolling stock or assets as collateral of their contractual obligation. As shown in rail companies' financial reports, most of them have a large amount of debt for their infrastructure investment procurement. Rail companies' huge debt results in high leverage level, accordingly the company attempt to lower its leverage level to prevent debt covenant violation by managing their earnings (Hoang \& Phung, 2019; Iatridis \& Kadorinis, 2009; Januarsi, Badina \& Febrianti, 2014; Lazzem \& Jilani, 2018) .

Third, rail companies are bound to the government policy to provide service 
obligations while, at the same time, demanded to work professionally to gain profit (Sudibya, 2007). Such a dilemma is faced by PT Kereta Api Indonesia (Persero) in Indonesia (Sukmoro Sulistiyono \& Karjoko, 2019) and Indian Railways in India (Ali, 2015) where they act as a public service company and profit-oriented company at the same time. As a consequence of this service obligation, the railroad service tariff is set below the normal price while the government injects the tariff gap through subsidy (Savoldi, 2009). A subsidy, according to World Trade Organization (WTO), is a financial contribution provided by the government that gives benefit to its beneficiary (Assagaf, Lestari \& Hamzah, 2016). The received subsidy is acknowledged as the company earnings. Since the government subsidy increases a company's profit, the company tends to manage its earnings by making it lower and stable in financial reports to evade public attention and supervision (Pappas, Walker, Xu \& Zeng, 2020).

It is interesting to investigate the dilemma faced by the rail companies as a public service and profit-oriented company when it is related to earnings management practices. Previous studies conducted by Bryer (1991), Sivakumar \& Waymire (2003), and Santos Cabalgante, Garcia Osma \& Romero (2019), revealed that earnings management practice exists in rail companies. Bryer's (1991) study reports an alleged fraud in the UK rail company called Railways Mania in 1840. George Hudson, the company manager, was alleged to manipulate the financial reports and commit accounting fraud to stole money from the shareholders. Sivakumar \& Waymire's (2003) study on accounting reports of the US railroad companies in the early 20th century found a decrease in income smoothing behavior after the Interstate Commerce Commission issued an accounting regulation in 1907 and 1908. Santos Cabalgante et al. (2019) study reports that in the 19th and 20th century, the rail companies' accounting reports were considered less reliable due to a lack of understanding of the conceptual framework of accounting, thus leading to practices of earnings man- agement in Spanish rail companies like MZA and NORTE. The company managers are involved in the accounting process to maintain the profitability and dividend payout level, which are viewed as a pressure that becomes a compelling reason to manipulate the financial report. As illustrated by several cases above, it is relevant to question the factors leading to earnings management behavior, especially in rail companies.

This study examines the phenomenon of earnings management in rail companies using the positive accounting theory's three hypotheses. The independent variables representing these hypotheses were the bonus plan, leverage, and government subsidy. The controlling variables were independent board (Sarkar, Sarkar \& Sen, 2008; Soliman \& Ragab, 2013; Tahir, Ibrahim \& Nurullah, 2019), audit committee (Muda et al., 2018; Suaryana, 2007), the firm size (Al-Absy et al., 2018; Lisboa, 2016; Soliman \& Ragab, 2013), and the inflation (Leuz, Nanda \& Wysocki, 2003; Scholtens \& Kang, 2013; Sumiyati \& Hartono, 2017). These variables were selected due to their significant effect on earnings management.

Inconsistency was noticed in previous studies on the bonus plan effect on earnings management (Anggraeni \& Widyaningsih, 2020). While Widowati (2013), Yustiningarti \& Asyik (2017), Simanjuntak \& Anugerah (2018), Alhadab (2018), Zubaidah \& Anwar (2019), Arianti \& Wijayanto (2019), Harakeh et al. (2019), Panjaitan \& Muslih (2019), and Anwar \& Gunawan (2020) report that bonus plan positively affects earnings management. Hassen (2014) found that a bonus plan negatively affects earnings management. Whereas Natalie \& Astika (2016), Fadhilia (2017), Zulaecha \& Yuli (2019), Dwiadnyani \& Mertha (2018), and Nurani \& Dillak (2019) found that bonus plan does not have any effect on earnings management.

Inconsistency is also noticed in studies on the effect of leverage on earnings management. Iatridis \& Kadorinis (2009), Januarsi et al. (2014), Wijaya \& Christiawan (2014), Lazzem \& Jilani (2018), and Hoang \& Phung (2019) found that leverage posi- 
tively affects earnings management. While Jelinek (2007), Alsharairi (2012), Zamri, Rahman \& Isa (2013), Afza \& Rashid (2014), Vakilifard \& Mortazavi (2016), and Suleiman (2019) found that leverage negatively affects earnings management. Meanwhile, Natalie \& Astika (2016) and Kaushik \& Kumar (2018) reported that leverage does not affect earnings management. Inconsistency is also found in studies on the effect of government subsidies on earnings management, as Pappas et al. (2020) found that government subsidies (representing political cost) positively affect earnings management while He (2016) reports that the government subsidy negatively affects earnings management .

Research in the Asia Pacific is a very interesting phenomenon because Asia Pacific countries are generally emerging market countries with good capital market growth but still weak in efforts to protect investors. As happened in China, India, Indonesia, South Korea, Malaysia, and Taiwan, there is still a high level of information asymmetry between companies and investors caused by the lack of assertiveness of the country's financial system (Sumiyati \& Hartono, 2017). The phenomenon can be utilized by the company's management to manipulate accruals on its financial statements to maximize the profits obtained from both investors and creditors .

This study aims to analyze whether the bonus plan, leverage, and government subsidies, as a part of the rail company's characteristics, affect the practice of earnings management in the Asia Pacific. Each country has different rules so the opportunity to do earning management depends on how strictly the supervision is carried out. Railway companies also have different business conditions than other companies. In addition, the economic and political conditions in this study also vary by country. The inconsistent result of previous studies is the primary reason why earnings management in rail companies is discussed in this study.

This study's results are expected to: First, it provides empirical evidence that opportunistic actions at railway companies are carried out by manipulating financial statements accrually. Earning management actions will continue to be carried out especially in a business environment with weak capital market regulation. Second, it provides an appropriate picture to assess the consequences of poor accrual quality. In countries with weak investor protection, opportunistic behavior in railway companies needs to be taken into consideration for investors and creditors to invest some of their funds.

This paper is organized as follows: Section 2 discusses the literature review and hypotheses development. Section 3 discusses the data selection and research model. In section 4 , the empirical evidence is presented. The further analysis is made in section 5 and the conclusion is presented in section 6 .

\section{LITERATURE REVIEW AND HYPOTHESIS DEVELOPMENT}

Agency Theory

Palestin (2009) explains that the concept of earnings management is inseparable from agency theory. According to Jensen \& Meckling (1976), agency theory defines an agency relationship between a company owner (principal) and a manager (agent) to run the company's operational activities. Due to information asymmetry between the principal and the agent, in which the agent holds more detailed information regarding the company, management takes this advantage for their interest (Muda et al., 2018). Eisenhardt (1989) argues that agency theory is closely associated with the human trait, namely self-interest, bounded rationality, and risk-averse.

\section{Positive Accounting Theory}

Positive accounting theory attempts to explain predicting phenomena in the accounting practice in the company (Watts \& Zimmerman, 1978). This theory is designed to depict and predict which company will, or will not, employed a certain method.

According to Wijaya \& Christiawan (2014), this theory is grounded from agency theory, a view that any management action contains certain motivation for its self- 
interest, thus leading to agent-principal conflicts. This theory is helpful to account for a company's behavior in making accounting policies (Hassen, 2014) and to understand why earnings management practices occur by associating it with the management's opportunistic behavior (Elhaj \& Mansor, 2019).

Associating the railway companies' characteristics and positive accounting theory's three hypotheses, the factors expected to influence a railway company earnings management are the bonus plan, the debt covenant, and the political cost. In other words, positive accounting theory acknowledges agency relationships between (1) the management and the owner, (2) the management and the creditor, and (3) the management and the government.

\section{Bonus Plan and Earnings Management}

Earnings management is closely related to profit and the company's achievement since the bonus given to the manager or employees is determined by their performance, which is indicated by the profit the company gains. Several studies mention differences in bonus schemes in some countries. Harakeh et al. (2019) report that in the UK, executive compensation was mostly determined based on profit. Hence, it is necessary to examine the effect of CEO compensation on earnings management. Shuto (2007) reports that the majority of US companies implements a bonus scheme for managers whereas most companies in Japan do not have a contract regarding executive bonuses. Thus, there is no regulation on mandatory disclosure of bonus compensation given by the company. Furthermore, Duong \& Evans (2015) report that bonus payment in Australia is different from that of the US. It was found that Australian companies prefer to pay the bonus using cash components while American companies prefer to use non-cash components (e.g., shares) because Australian tax regulation stipulates that shares, options, or other rights are assessed and taxed in higher amounts compared to the cash bonus.

Healy (1985) found that a bonus plan may drive management to manage earnings through discretionary accrual by increasing profit to maximize their bonus. This is supported by findings of studies conducted by Widowati (2013), Yustiningarti \& Asyik (2017), Arianti \& Wijayanto (2019), Simanjuntak \& Anugerah (2018), Panjaitan \& Muslih (2019), Alhadab (2018), Zubaidah \& Anwar (2019), and Anwar \& Gunawan (2020), showing that bonus plan positively affects earning management. A bonus plan may drive the manager to increase the company profit to make it look satisfying to receive more bonuses.

Hassen (2014) argues that a bonus plan negatively affects earnings management since a bonus plan is considered a means to minimize agency conflicts. A bonus plan is expected to diminish management's opportunistic behavior.

Based on the positive accounting theory's bonus plan hypothesis, the bonus plan emerges as one of the factors driving the management to report a profit to receive profit-based bonuses. When profit is used to determine the bonus, management may increase the bonus by overstating profit. Based on the description, it is expected that:

H1: Bonus plan positively affects earnings management.

\section{Leverage and Earnings Management}

The debt covenant hypothesis proposed by Watts \& Zimmerman (1978) argues that when a company is closer to accountingbased debt covenant violation, the management may evade it by managing its earnings (Kaushik \& Kumar, 2018). The debt covenant in this study is proxied by leverage to compare the total debt to the total asset. A high leverage level puts a company at risk of default, thus driving the manager to manage earnings by making policies to increase profit (Zubaidah \& Anwar, 2019).

A previous study in the Indonesian context was done by Januarsi et al. (2014) that reported a positive effect of leverage on earnings management. The study used 141 Indonesian companies from 2009 to 2014 as the sample of the study. They argued that a high leverage level motivates managers to accrually manipulate the prof- 
it because the company attempts to have a better bargaining position to renegotiate the debt. It is supported by Shahzad, Rauf, Saeed \& Al Barghouthi (2017) who also found a positive effect of leverage on earnings management among companies listed in the Pakistan Stock Exchange in 20072014. Lazzem \& Jilani's (2018) study on 185 French non-financial corporations in 2006-2012 and Hoang \& Phung's (2019) study on 241 companies listed in Vietnam Stock Exchange in 2010-2016 also found that the company's leverage positively affects earnings management.

These reports contradict the findings of Alsharairi (2012), Jelinek (2007), Zamri et al. (2013), and Suleiman (2019) on the negative effect of leverage on earnings management. It is argued that a high leverage level puts the managers in caution to perform earnings management due to creditors' tight monitoring.

Considering railway companies' leverage characteristics, we employed the debt covenant hypothesis, where leverage may influence earnings management behavior in railway companies. When the company has a debt covenant, the management would prefer accounting procedures by engaging with earnings management practice to prevent debt violation that adversely affects the creditor's trust. Based on the description, it is expected that:

H2: Leverage positively affects earnings management .

\section{Government Subsidy and Earnings Man- agement}

Schreiner (1997) states that the government subsidy defines a form of support to improve a company's innovation and sales. It is viewed as the government's tool to redistribute a company's wealth.

According to Zhao et al. (2019), there are two categories of subsidy: 1) project subsidies and 2) policy subsidies. The former is given to the company with outstanding performance and less affected by the government policies. The latter is given to support companies that face financial distress, especially when their product meets the state's long-term policy and is affected by the government policies (Zhao et al.,
2019). The government subsidy for railway companies could be viewed as the government's policy to expedite the state's economic development. The company's motivation to gain subsidy is to compensate the company's consumption, investment, and promotion (Zhao et al., 2019).

Pappas et al. (2020) examine the effect of the government subsidy on income smoothing by using companies listed in the US Stock Market as the sample. Pappas et al. (2020) suggest that government subsidies positively affect earnings management. Companies that receive government subsidies tend to manage their earnings by reporting lower profit and stable profit to evade public attention and supervision.

He (2016) studies the effect of Chinese governments' subsidies and fiscal support (i.e., tax incentives) on Chinese companies' earnings management behavior. He (2016) argues that the governments' subsidy negatively affects earnings management behavior. The result of the study showed that companies that receive the government subsidy or fiscal support tend to exhibit lower earnings management behaviors Because they view the government subsidy or fiscal support as a substitution to their earnings management behavior. Having the government's fiscal support, the company may achieve the targeted profit and lose interest in managing its earnings.

Following the political cost hypothesis, we believe that fear of public supervision due to government subsidy motivates the company to engage in earnings management to avoid political reactions (Pappas et al., 2020). Companies are sometimes blamed due to public fund abuse over subsidy programs that are deemed ineffective (Pappas et al., 2020). Companies that receive subsidies may draw public attention when they report fluctuating profits. Accordingly, they tend to avoid reporting overly high or overly low profit by applying accrual policy to avoid potential political reactions. Based on the description, it is expected that:

H3: Government subsidy positively influence earnings management 


\section{RESEARCH METHODS}

\section{Population and Sample}

The population of this study was railway companies in Asia-pacific countries published in International Union of Railways (UIC) and www.wikipedia.co.id. Classification of countries, including Asia Pacific countries, followed the research of Wijayana \& Gray (2019). They took information from the website of The Daniel K. Inouye Asia Pacific Center for Security Studies (DKIAPCSS, 2018). The source of data in this study was secondary data taken from annual reports published on the companies' official websites from 2010 to 2019. This period was selected due to the limited data availability. The sample of the study was selected purposively following these criteria: 1) a railway company that provides passenger transportation services, 2) a company that publishes an annual report on its official website, 3) a company that publishes an annual report in English, 4) The published annual report meets the data required in the present study. The data collected consists of different types of currency, then the next step is to convert the nominal of that currency into rupiah (IDR) using the Bank Indonesia middle rate at the reporting date.

\section{Variables and Measurement}

This study involved three independent variables, i.e., bonus plan, leverage, and government subsidy, that may affect the dependent variable, i.e., earnings management. A bonus plan is defined as a company policy and procedure to reward the managers for their performance during a certain period (Panjaitan \& Muslih, 2019). Companies with compensation plans will use accounting procedures to give bonuses for their interest. According to Nurani \& Dillak (2019), a bonus is given when the management manages to meet the company target. The bonus plan is proxied by the amount of the received bonus, which can be seen in the financial report. The bonus was calculated using the natural logarithm of the total bonus value mentioned in the financial report (Nurani \& Dillak, 2019).

According to Agustia (2013), leverage describes the capital that is obtained from debt, which is used to fund the company's operation and investment. Leverage was measured by Debt Ratio (DR), i.e., comparison of total debt and total asset, as done in Nouri \& Abaoub (2014), Alsharairi (2012), Zamri et al. (2013), and Lopes (2018) studies. DR is a ratio used to measure company solvency. A company is considered solvent if it has an adequate asset to pay its obligation (Natalie \& Astika, 2016).

The government subsidy is defined as the support given to improve a company's innovation and sales (Schreiner, 1997). It was measured using Subsidy Dependence Index (SDI) developed by Assagaf, Yusoff \& Hassan (2017).

This study uses the dependent variable earning management as measured by cross-sectional modified jones model since it is the most accurate model to detect earnings management (Dechow, Sloan \& Sweeney, 1995; Soliman \& Ragab, 2013; Ujah \& Brusa, 2014). This model provides the most accurate estimation to separate the management's accrual policy from the accrual policies made due to the company's changes in economic scale.

The stages in discretionary accruals modified model jones begin by calculating the total accrual in $t$ period, as stated in the (1) equation.

$$
\mathrm{TA}_{\mathrm{it}}=\mathrm{NI}_{\mathrm{it}}-\mathrm{CFO}_{\mathrm{it}}
$$

Where $\mathrm{TA}_{\mathrm{it}}$ :total accrual of company $\mathrm{i}$ during period $\mathrm{t}$; $\mathrm{NI}_{\mathrm{it}}$ : revenue of company I in period t; $\mathrm{CFO}_{\mathrm{it}}$ : cash flow of company $\mathrm{i}$ operational activities in $t$ period.

The next step was to find the coefficient value and total accrual regression to determine the coefficient value $\beta_{1}, \beta_{2}$, and $\beta_{3}$ using regression technique formulated in the (2) equation:

$\frac{T A_{i t}}{A_{i t-1}}=\beta_{1}\left(\frac{1}{A_{i t-1}}\right)+\beta_{2}\left(\frac{\Delta \operatorname{Rev}_{i t}}{A_{i t-1}}\right)+\beta_{3}\left(\frac{P P E_{i t}}{A_{i t-1}}\right)+\varepsilon_{i t}$

Where TA: company i's total accrual in period t; $\Delta \operatorname{Rev}_{\mathrm{it}}$ : company i's earnings in period $t$ minus earnings in $t-1 ; \mathrm{PPE}_{\mathrm{it}}$ : company i's gross fixed asset in period $t$; $A_{i t-1}$ : company i's total asset in period $t-1$; 
$\varepsilon_{\mathrm{it}}$ company i's error value in period t.

After that, using the regression coefficient above, the non-discretionary accruals (NDA) value is calculated using the formula (3):

$N D A_{i t}=\beta_{1}\left(\frac{1}{A_{i t-1}}\right)+\beta_{2}\left(\frac{\Delta \operatorname{Rev}_{i t}}{A_{i t-1}}-\frac{\Delta R e c_{i t}}{A_{i t-1}}\right)+\beta_{3}\left(\frac{P P E_{i t}}{A_{i t-1}}\right)$

Where NDA $_{i t}$ : non-discretionary accruals of the company $\mathrm{i}$ in period t; $\Delta \operatorname{Rec}_{\mathrm{it}}$ : account receivable of the company $i$ in period $t$ minus receivables in period $t-1$;

Once the NDA value is obtained, the discretionary accrual is calculated using (4) equation:

$$
\mathrm{DA}_{\mathrm{it}}=\frac{\mathrm{TA}_{\mathrm{it}}}{\mathrm{A}_{\mathrm{it}-1}}-\mathrm{NDA}_{\mathrm{it}}
$$

Where, $\mathrm{DA}_{\mathrm{it}}$ : discretionary accrual of the company $\mathrm{i}$ in period $\mathrm{t}$.

The present study used several controlling variables, independent commissioner board, audit committee, firm size, and inflation. The independent commissioner board is calculated by dividing the number of independent commissioners with the total number of commissioner board members of the selected companies, as done in Anggraeni \& Hadiprajitno (2013) and Hastuti, Setiawan \& Widagdo (2020)'s studies. The audit committee was measured numerically by seeing the number of audit members the company has. This measurement is consistent with studies conducted by Anggraeni \& Hadiprajitno (2013) and Hastuti et al.
(2020). The firm size was measured based on the company's total assets, obtained from the company's balance sheet, consistent with Alhadab (2018), Kaushik \& Kumar (2018), and Suleiman (2019)'s studies. Inflation as a factor of the macro-economic indicators to control data cross country used (Sumiyati \& Hartono, 2017). Inflation is measured as a percentage of a country's inflation from 2010 to 2019.

The equation model in this study was as follow:

$$
\begin{aligned}
\mathrm{Em}_{\mathrm{it}}= & \beta_{0}+\beta_{1} \mathrm{BPI}_{\mathrm{it}}+\beta_{2} \mathrm{LEV}_{\mathrm{it}}+\beta_{3} \mathrm{GS}_{\mathrm{it}}+\beta_{4} \mathrm{IB}_{\mathrm{it}}+ \\
& \beta_{5} \mathrm{AC}_{\mathrm{it}}+\beta_{6} \mathrm{FZ}_{\mathrm{it}}+\beta_{7} \mathrm{INF}_{\mathrm{it}}+\varepsilon_{\mathrm{it}} \ldots \ldots \ldots \ldots \ldots .(5)
\end{aligned}
$$

Where, Em $_{\mathrm{it}}$ :Earnings Management; $\beta_{0}$ : constant; $\beta_{1}-\beta_{7}$ :regression coefficient; $\mathrm{BPI}_{\mathrm{it}}$ : Bonus Plan; $\mathrm{LEV}_{\mathrm{it}}$ :Leverage; $\mathrm{GS}_{\mathrm{it}}$ :Government Subsidy; $\mathrm{IB}_{\mathrm{it}}$ : Independent Board; $\mathrm{AC}_{\mathrm{it}}$ : Audit Committee; $\mathrm{FZ}_{\mathrm{it}}$ : Firm Size; $\mathrm{INF}_{\mathrm{it}}$ : Inflation; $\varepsilon_{\mathrm{it}}$ : error.

\section{ANALYSIS AND DISCUSSION}

The population of the study was rail companies in Asia Pacific countries in 2010 -2019. The sample of the study was 171 financial reports of rail companies in Asia Pacific countries.

The following table 1 and table 2 describes the sample used in this study. The observation of the study was 171 financial reports of 25 railway companies in the 2010-2019 period. Due to the data availability issue, we applied unbalanced panel data, referring to a condition where crosssectional units have an unequal number of time-series observations (Biørn, 2004).

Table 1.

Number of Selected Companies

\begin{tabular}{lc}
\hline \multicolumn{1}{c}{ Information } & Total \\
\hline Rail companies in Asia-Pacific region & 170 \\
Companies without passenger service & $(38)$ \\
Companies that did not publish financial report & $(78)$ \\
Companies that did not meet the required data & $(29)$ \\
Number of samples & 25 \\
Number of financial reports examined from 2010-2019 (25 x 10) & 250 \\
Number of financial reports that were not found from 2010-2019 & $(79)$ \\
Final sample & 171 \\
\hline
\end{tabular}


Earning management in this study was measured by discretionary accruals. As presented in Table 3, the mean of earnings management was 0.0436 with a standard deviation of 0.2722 . The highest earnings management score was 1.0037, found in Metra company in 2011, while the lowest earnings management score was -0.9084 that was found in NSW Trains company in 2015. This result showed that the rail companies manage their earnings by either increasing or decreasing the profit.

The mean score of the bonus plan variable was 23.677 with a standard deviation of 2.2464. The mean score that is higher than the standard deviation value indicates that the bonus plan data were homogeneous. This variable also exhibited the highest score of 27.803 in Amtrak company in 2017 and the lowest score of 16.227 in Korea Railroad Corporation in 2016.

The mean value of leverage was 0.5978 with a standard deviation of 0.5622 . The value indicated that the average rail companies have a debt of $\mathrm{Rp} 0.598$ for each Rp. 1.00 asset they hold.

The highest leverage was 3.0798,

Table 2.

List of Selected Companies

\begin{tabular}{lcc}
\hline \multicolumn{1}{c}{ Company } & Country & $\begin{array}{c}\text { Number of } \\
\text { Observation }\end{array}$ \\
\hline Amtrak & Amerika & 6 \\
Caltrain & Amerika & 10 \\
China Railway Group Limited & China & 6 \\
Kereta Api Tanah Melayu Berhad & Malaysia & 6 \\
Kiwirail & Selandia Baru & 7 \\
Korea Railroad Corporation & Korea & 5 \\
Light Rail Transit Authority & Philipina & 4 \\
Metra & Amerika & 10 \\
Metro Taipei & Taiwan & 10 \\
Metrolink & Canada & 9 \\
Metropolitan Transportation Authority & Amerika & 8 \\
Miami Metro Rail & Amerika & 4 \\
MRT Jakarta & Indonesia & 1 \\
MTR Corporation Limited & Hongkong & 8 \\
NSW Trains & Australia & 5 \\
Philippine National Railways & Philipina & 7 \\
PT Kereta Api Indonesia (Persero) & Indonesia & 9 \\
Queensland Rail & Australia & 4 \\
Russian Railways & Rusia & 9 \\
Taiwan High Speed Rail Corporation & Taiwan & 4 \\
Toronto Transit Commision & Canada & 10 \\
Tri Rail & Amerika & 10 \\
V/Line & Australia & 6 \\
Via Rail Canada & Canada & 9 \\
Southern California Regional Rail Authority & Amerika & 4 \\
Total & & 171 \\
\hline & & \\
\hline
\end{tabular}


found in Kereta Api Tanah Melayu Berhad in 2015, and the lowest leverage was 0.0179 , found in Tri Rail company in 2011.

The mean value of government subsidy was 1.0217 with a standard deviation of 2.0292. The highest value of government subsidy was 10.873 , held by Kereta Api Tanah Melayu Berhad in 2016, and the lowest value was 0.0001 , found in Taiwan High-Speed Rail Corporation in 2017.

Regarding the independent commissioner, the mean value was 0.4613 with a standard deviation of 0.3516 . This value indicated that rail companies had met the minimum requirement of $30 \%$ of an independent commissioner. The mean value of the audit committee variable was 2.5029 with a standard deviation of 2.1265. The mean value of the firm age variable was 31.355 with a standard deviation of 1.9127 . The highest value of the firm size variable was 35.282, found in China Railways Group Limited, while the lowest value was 28.240, found in NSW Trains.

This study employed panel data regression analysis by using three approaches, Common Effect Model (CEM),
Fixed Effect Model (FEM), and Random Effect Model (REM). From these three models, Chow, Hausman, and Lagrange

The Chow test result showed a probability value on Cross-section ChiSquare of 0.0000 , meaning that the recommended panel data regression model, based on the Chow test result, was the Fixed Effect Model (FEM). The next step was conducting the Hausman test. The result showed a probability value on the Cross-section Chi-square of 0.2061 . Following the Hausman test result, REM was the recommended model. The last step was conducting the langrage-multiplier test, showing that both values on BreuschPagan were 0.0000. To conclude, the recommended regression model in this study was the Random Effect Model (REM).

Table 5 presents the panel data analysis result by using REM. As presented in Table 5. Multiplier tests were conducted to determine the most appropriate regression model. The result of these tests is presented in Table 4.

The bonus plan variable did not have a significant effect because the $\mathrm{p}$ value was higher than the significance level

Table 3.

Descriptive Statistical Analysis

\begin{tabular}{lrrrrrrrr}
\hline & \multicolumn{1}{c}{$\mathrm{Em}_{\text {it }}$} & \multicolumn{1}{c}{$\mathrm{BPI}_{\mathrm{it}}$} & \multicolumn{1}{c}{$\mathrm{LEV}_{\mathrm{it}}$} & \multicolumn{1}{c}{$\mathrm{GS}_{\mathrm{it}}$} & \multicolumn{1}{c}{$\mathrm{IB}_{\mathrm{it}}$} & $\mathrm{AC}_{\mathrm{it}}$ & $\mathrm{FZ}_{\text {it }}$ & $\mathrm{INF}_{\text {it }}$ \\
\hline Mean & 0.0436 & 23.677 & 0.5978 & 1.0217 & 0.4613 & 2.5029 & 31.355 & 2.2733 \\
Median & -0.0076 & 23.864 & 0.4819 & 0.1995 & 0.5000 & 1.0000 & 30.948 & 1.9100 \\
Maximum & 1.0037 & 27.803 & 3.0798 & 10.873 & 1.0000 & 8.0000 & 35.282 & 15.530 \\
Minimum & -0.9084 & 16.227 & 0.0179 & 0.0001 & 0.0000 & 0.0000 & 28.240 & 0.1200 \\
Std. Dev. & 0.2722 & 2.2464 & 0.5622 & 2.0292 & 0.3516 & 2.1265 & 1.9127 & 1.7839 \\
Skewness & 2.0834 & -0.7526 & 2.2937 & 3.1023 & 0.0204 & 0.9438 & 0.3297 & 3.3284 \\
Kurtosis & 9.4065 & 4.5801 & 9.6508 & 12.680 & 1.4578 & 2.9536 & 2.0824 & 20,934 \\
Jarque-Bera & 416.13 & 33.934 & 465.10 & 941.90 & 16.957 & 25.403 & 9.0972 & 2607.6 \\
Probability & 0.0000 & 0.0000 & 0.0000 & 0.0000 & 0.0002 & 0.0000 & 0.0106 & 0.0000 \\
Sum & 7.4610 & 4048.7 & 102.21 & 174.72 & 78.880 & 428.00 & 5361.7 & 388.74 \\
Sum Sq. Dev. & 12.599 & 857.85 & 53.723 & 699.99 & 21.015 & 768.75 & 621.91 & 541.01 \\
Observations & 171 & 171 & 171 & 171 & 171 & 171 & 171 & 171 \\
\hline
\end{tabular}

$\mathrm{BPI}_{\mathrm{it}}$ : Bonus Plan; $\mathrm{LEV}_{\mathrm{it}}$ :Leverage; $\mathrm{GS}_{\mathrm{it}}$ : Government Subsidy; $\mathrm{IB}_{\mathrm{it}}$ : Independent Board; $\mathrm{AC}_{\mathrm{it}}$ :

Audit Committee; $\mathrm{FZ}_{\mathrm{it}}$ : Firm Size; $\mathrm{INF}_{\mathrm{it}}$ : Inflation 
of 0.05. Meanwhile, leverage and government subsidy exhibited a positive, significant effect on earnings management as the p-value was lower than the significance level of 0.05 . Following the result, it could be concluded that only $\mathrm{H} 2$ and $\mathrm{H} 3$ are supported by the data, while H1 was not supported.

Regarding the controlling variables, it was found that independent board and committee audits negatively and significantly affect earnings management as the p-value was lower than the significance level of 0.05 . It was found that firm size and inflation rate did not have a significant effect as the p-value was higher than 0.05 .

\section{The Effect of Bonus Plan on Earnings Management}

The panel data regression analysis result indicated that the railway companies' bonus plan did not significantly influence their earnings management behavior. This research is in line with research Nazir (2014) who suggests that the increase or decrease in a company bonus plan may result in constant earnings management behavior. This occurs probably because most of the railway companies possess a compensation committee that is responsible for assessing the performance and issuing a recommendation on the amount of the bonus (Fadhilia, 2017). According to Murphy \& Jensen (2011), companies with compensation committees could determine a proper performance measurement and goal to minimize earnings management practice. The results of this study also support the results of the study Natalie \& Astika (2016), Dwiadnyani \& Mertha (2018), Zulaecha \& Yuli (2019), and Nurani \& Dillak (2019) who

Table 4.

Panel Data Regression Tests Results

\begin{tabular}{clccc}
\hline No & \multicolumn{1}{c}{ Test } & $\begin{array}{c}\text { Common } \\
\text { Effect Model }\end{array}$ & $\begin{array}{c}\text { Fixed Effect } \\
\text { Model }\end{array}$ & $\begin{array}{c}\text { Random Effect } \\
\text { Model }\end{array}$ \\
\hline 1 & Chow Test & $\checkmark$ & $\checkmark$ \\
2 & Hausman Test & & $\checkmark$ \\
3 & Lagrange Multiplier Test & & & $\checkmark$ \\
The selected method & & & $\checkmark$ \\
\hline
\end{tabular}

Table 5.

Panel Data Regression Random Effect Model Result

\begin{tabular}{|c|c|c|c|c|}
\hline Variable & Coefficient & Std. Error & t-Statistic & Prob. \\
\hline $\mathrm{C}$ & -0.1471 & 0.5460 & -0.2696 & 0.7878 \\
\hline $\mathrm{BPI}_{\mathrm{it}}$ & 0.0075 & 0.0119 & 0.6288 & 0.5304 \\
\hline $\mathrm{LEV}_{\text {it }}$ & 0.1050 & 0.0408 & 2.5726 & $0.011^{* *}$ \\
\hline $\mathrm{GS}_{\text {it }}$ & 0.0327 & 0.0126 & 2.5753 & $0.0109 * *$ \\
\hline $\mathrm{IB}_{\mathrm{i}}$ & -0.1683 & 0.0369 & -4.5584 & $0.0000 * *$ \\
\hline $\mathrm{AC}_{\mathrm{i}}$ & -0.0194 & 0.0065 & -2.9781 & $0.0033^{* * *}$ \\
\hline $\mathrm{FZ}_{\mathrm{i}}$ & 0.0007 & 0.0198 & 0.0362 & 0.9711 \\
\hline INF & 0.0018 & 0.0057 & 0.3199 & 0.7495 \\
\hline R-squared & 0.2559 & \multicolumn{2}{|c|}{ Mean dependent var } & 0.0044 \\
\hline $\begin{array}{l}\text { Adjusted R- } \\
\text { squared }\end{array}$ & 0.2239 & \multicolumn{2}{|c|}{ S.D. dependent var } & 0.0922 \\
\hline S.E. of regression & 0.0813 & \multicolumn{2}{|c|}{ Sum squared resid } & 1.0763 \\
\hline F-statistic & 8.0061 & \multicolumn{2}{|c|}{ Durbin-Watson stat } & 1.5942 \\
\hline Prob (F-statistic) & $0.0000 * *$ & \multicolumn{2}{|c|}{$\begin{array}{l}\text { Note: } * *=\text { Significant at the level of } \\
0,05\end{array}$} & \\
\hline
\end{tabular}


did not find the effect of bonus plan on earnings management.

\section{The Effect of Leverage on Earnings Management}

This study found that leverage positively affected earnings management. In other words, railway companies with a higher leverage level exhibited higher earnings management behavior. This is consistent with Wijaya \& Christiawan (2014) who state that a high leverage level indicates that the company is at risk of default, thus motivating the management to manage their earnings.

Investment in railway companies is capital-intensive. Accordingly, the company management will attempt to minimize the leverage ratio by managing its earnings to meet the debt covenant requirements (Zulaecha \& Yuli, 2019). It was done so that the company maintains the creditor's trust so that they can have additional debt when needing more funds to realize their investment projects. This study supports the debt covenant hypothesis stating that one of the companies' motivations for engaging with earnings management is the debt covenant that forces them to meet the requirements during the agreement period (Watts \& Zimmerman, 1978). The results of this study at the same time support the results of research conducted by Januarsi et al. (2014), Shahzad et al. (2017), Lazzem \& Jilani (2018), and Hoang \& Phung (2019) who found that leverage positively affects earnings management behavior.

\section{The Effect of Government Subsidies on Earnings Management}

This study found that government subsidies significantly and positively affects earnings management behaviors. This indicates that when railway companies receive large government subsidies, their earnings management behavior tends to increase. It is consistent with Pappas et al. (2020) finding that companies receiving government subsidies attempt to manage their earnings by lowering their profit so that they report a stable financial statement to avoid public attention and supervision.

For the political purpose, the govern- ment subsidies railway companies receive aim to provide public services. However, limited laws and regulations on the procedure, form, and purpose of subsidies lead to poor supervision of the distribution and use of the subsidy (Bu, Zhang \& Wang, 2017) making the companies manage their earnings easily. Earnings management and public perception are two important aspects that should be addressed properly because a company's financial information will be interpreted rationally and logically by its users. Therefore, it is necessary to design an accounting standard to acknowledge the government subsidy to provide financial report users with feedbacks during the decision-making process.

\section{CONCLUSION}

The purpose of this study was to examine the effect of the bonus plan, leverage, and government subsidy on rail companies' earnings management behavior. Using data from railway companies in Asia Pacific countries, this study provides international, empirical evidence of earnings management behaviors in railway companies. This study provides evidence that a bonus plan does not affect earnings management behaviors, while leverage and government subsidy positively affects earnings management.

Out of the positive accounting theory's three hypotheses (Watts \& Zimmerman, 1978), only the bonus plan hypothesis does not affect earnings management behaviors in railway companies. This occurs because these companies have already had a competent compensation committee to determine the amount of bonus. Thus, the bonus the management receives does not depend on the company's earnings management behaviors. Meanwhile, the debt covenant hypothesis (proxied by leverage) and the political cost hypothesis (proxied by government subsidy) are found to support the railway companies' earnings management behavior.

This result indicates that railway companies with higher leverage levels attempt to evade debt violations by managing their earnings. Furthermore, railway companies that receive a large 
number of government subsidies also tend to manage their earnings to make their reported profit look stable to avoid public supervision. The earnings management behavior of railway companies significantly influences their financial report quality because they fail to reflect the actual condition of the company. Such a report could not be used to predict the company's future performance, thus misleading the users' decision-making process.

We suggest the financial regulator pay more attention to railway companies with high leverage levels and those receiving large government subsidies since they are prone to earnings management behavior that exceeds the regulated limit, potentially leading to fraud (Naidu \& Patel, 2013). For the company management, it is necessary to disclose the company's actual condition to creditors and other external parties to prevent information asymmetry and eventually minimize earnings management behavior.

\section{LIMITATIONS AND SUGGESTIONS.}

Due to limited data and time, this study only focuses on examining accrual-based earnings management in railway companies. Hence, future studies are recommended to add real-based earnings management to discover more results. Real -based earning management is very relevant applied in railway companies. Companies often give discounts to customers to increase train ticket sales. In addition, even though the railway company is a service company but the company also conducts production activities in the form of maintenance of locomotives and trains that later generate the total cost of production to be used as information to determine the price of train ticket sales. Railway companies are often under public scrutiny because of their political connections with the government, so that companies will prefer to use real-based earning management rather than accrual-based earning management because it is considered more difficult to detect.

This study involved only data from railway companies in the Asia Pacific region. Future studies are suggested to extend the object of the study by involving railway companies in European and African countries. The level of competition for railways companies in the region is quite competitive. Moreover, several railway companies in European such as Deutsche Bahn (Germany) and SNCF (France) are among the top ten railway companies with the highest revenue in the world in 2020. So, it will be very interesting to research earnings management in these companies.

\section{REFERENCES}

Abdullah, W.R.W., Maruhun, E.N.S., \& Ahmad, M. (2018). Mitigating earnings management: Adoption of IFRS and corporate governance practices in Malaysia. Journal of Academic Research in Business and Social Sciences, 8(2), 760-772.

Afza, T., \& Rashid, B. (2014). Oportunistic earning management, debt and diversification: Empirical evidence for manufacturing firm of Pakistan. Science International, 26(5), 24892494.

Agustia, D. (2013). Pengaruh faktor good corporate governance, free cash flow, dan leverage terhadap manajemen laba. Jurnal Akuntansi dan Keuangan, 15(1), 27-42.

Al-Absy, M.S.M., Ismail, K.N.I.K., \& Chandren, S. (2018). Board chairmen's involvement in the nomination and remuneration committees and earnings management. Australasian Accounting, Business and Finance Journal, 12(4), 60-76.

Alhadab, M. (2018). The impact of executive compensation and audit quality on accrual-based and real-based earnings management: Evidence from Jordan. Corporate Ownership and Control, 15 (2-1), 209-219.

Ali, S. (2015). Indian Railways: A comprehensive study on social service obligation. Research Review Journals, 03(08), 2455-3085.

Alsharairi, M. (2012). Does high leverage impact earnings management? Evidence from non-cash mergers and acquisitions. Journal of Financial and Economic Practice, 12(1), 17-33.

Anggraeni, R.M., \& Hadiprajitno, B. (2013). Pengaruh struktur kepemilikan manajerial, ukuran perusahaan, dan praktik corporate governance terhadap manajemen laba. 
Diponegoro Journal of Accounting, 754-766.

Anggraeni V.J., \& Widyaningsih, A. (2020). Can bonus compensation improve earnings management? Innovative Journal of Medical and Health Science, 7(7), 2754.

Anwar, A., \& Gunawan, G. (2020). Can cash holding, bonus plan, company size and profitability affect income smoothing practices? Point of View Research Accounting and Auditing, 1 (3), 49-56.

Arianti, E., \& Wijayanto, S.A. (2019). Pengaruh kompensasi bonus, debt covenant dan firm size terhadap earning management pada perusahaan manufaktur. Sekolah Tinggi Ilmu Ekonomi AMM Mataram.

Assagaf, A., Lestari, S., \& Hamzah, M. (2016). The effects of the implementation of earning management and subsidy policy: A case study of government company. OIDA International Journal of Sustainable Development, 9(10), 2334.

Assagaf, A., Yusoff, Y.M., \& Hassan, R. (2017). Government subsidy, strategic profitability and its impact on financial performance: Empirical evidence from Indonesia. Investment Management and Financial Innovations, 14(3), 135-147.

Azzali, S., \& Mazza, T. (2018). Effect of European audit firms on cost of debt and earnings management in private clients audit market segment. African Journal of Business Management, 12(11), 294-315.

Biørn, E. (2004). Regression systems for unbalanced panel data: A stepwise maximum likelihood procedure. Journal of Econometrics, 122(2), 281291.

Bryer, R.A. (1991). Accounting for the "railway mania" of 1845-a great railway swindle? Accounting, Organizations and Society, 16(5-6), 439-486.

Bu, D., Zhang, C., \& Wang, X. (2017). Purposes of government subsidy and firm performance. China Journal of Accounting Studies, 5(1), 100-122.

Dechow, P.M., Sloan, R.G., \& Sweeney, A.P. (1995). Detecting earnings management. Accounting Review, 193-225.

Duong, L., \& Evans, J. (2015). CFO compensation: Evidence from Australia. Pacific-Basin Finance
Journal, 35, 425-443.

Dwiadnyani, N.M., \& Mertha, I.M. (2018). Pengaruh bonus plan dan corporate governance pada income smoothing. E-Jurnal Akuntansi Universitas Udayana, 24(2), 1600-1631.

Eisenhardt, K.M. (1989). Agency theory: An assessment and review. Academy of Management Review, 14(1), 57-74.

Elhaj, E.B., \& Mansor, N. (2019). Earnings management in developed and developing countries: A review of recent literature. American Based Research Journal, 8(01), 2304-7151.

Fadhilia, W. (2017). Pergantian CEO, penghindaran pajak, kompensasi eksekutif dan manajemen laba studi kausalitas pada perusahaan manufaktur Indonesia. Jurnal Ilmiah Mahasiswa Ekonomi Akuntansi, 2(3), 86-99.

Harakeh, M., El-Gammal, W., \& Matar, G. (2019). Female directors, earnings management, and CEO incentive compensation: UK evidence. Research in International Business and Finance, 50, 153-170.

Hassen, R.B. (2014). Executive compensation and earning management. International Journal of Accounting and Financial Reporting, 4(1), 84.

Hastuti, S., Setiawan, D., \& Widagdo, A.K. (2020). Substitution between accrual and real earnings management: The role of independent commissioners and audit committee. Jurnal Keuangan dan Perbankan, 24(2), 225 -240 .

He, G. (2016). Fiscal support and earnings management. The International Journal of Accounting, 51(1), 57-84.

Healy, P.M. (1985). The effects of bonus schemes on accounting decisions. Journal of Accounting and Economics, 7(1-3), 85-107.

Hoang, K.M.T., \& Phung, T.A. (2019). The effect of financial leverage on real and accrual-based earnings management in Vietnamese firms. Economics \& Sociology, 12(4), 299333.

Iatridis, G., \& Kadorinis, G. (2009). Earnings management and firm financial motives: A financial investigation of UK listed firms. International Review of Financial Analysis, 18(4), 164-173.

Ilyas, M., Ahmad, A., Khan, M.T., \& Khan, I. (2018). The impact of corporate governance on earnings management: Empirical evidence 
from Pakistan. Journal of Research in Social Sciences, 6(2), 256-271.

Januarsi, Y., Badina, T., \& Febrianti, D. (2014). Leverage, corporate strategy and earnings management: Case of Indonesia. GSTF Journal on Business Review (GBR), 3(2).

Jelinek, K. (2007). The effect of leverage increases on earnings management. The Journal of Business and Economic Studies, 13(2), 24.

Jensen, M.C., \& Meckling, W.H. (1976). Theory of the firm: Managerial behavior, agency costs, and ownership structure. In Economics social institutions (pp. 163-231). Springer.

Kaushik, N., \& Kumar, S. (2018). Leverage effect on earnings management: Evidence from India. IUP Journal of Accounting Research \& Audit Practices, 17(4).

Lassoued, N., Attia, M.B.R., \& Sassi, H. (2017). Earnings management and ownership structure in emerging market: Evidence from banking industry. Managerial Finance, 43(10), 0307-4358.

Lawrence, M., \& Ollivier, G. (2014). Private capital for railway development. China Transport Topic, 10, 90117.

Lazzem, S., \& Jilani, F. (2018). The impact of leverage on accrual-based earnings management: The case of listed French firms. Research in International Business and Finance, $44,350-358$

Lemma, T.T., Negash, M., \& Mlilo, M. (2013). Determinants of earnings management: Evidence from around the world. Available at SSRN 2370926.

Leuz, C., Nanda, D., \& Wysocki, P.D. (2003). Earnings management and investor protection: an international comparison. Journal of Financial Economics, 69(3), 505-527.

Lisboa, I. (2016). Impact of financial crisis and family control on earning management of Portuguese listed firms. European Journal of Family Business, 6(2), 118-131.

Lopes, A.P. (2018). Audit quality and earnings management. Athens Journal of Business \& Economics, 4(2), 179-192.

Muda, I., Maulana, W., Sakti, S.H., \& Indra, N. (2018). The analysis of effects of good corporate governance on earnings management in Indonesia with panel data approach. Iranian Economic Review, 22(2), 599-625.

Murphy, K.J., \& Jensen, M.C. (2011). CEO bonus plans: And how to fix them. Harvard Business School NOM Unit Working Paper, 12-22.

Naidu, D., \& Patel, A. (2013). A comparison of qualitative and quantitative methods of detecting earnings management: Evidence from two Fijian private and two Fijian stateowned entities. Australasian Accounting, Business and Finance Journal, 7(1), 79-98.

Natalie, N., \& Astika, I.B.P. (2016). Pengaruh cash holding, bonus plan, reputasi auditor, profitabilitas dan leverage pada income smoothing. E-Jurnal Akuntansi Universitas Udayana, 15 (2), 943-972.

Nazir, H. (2014). Pengaruh kepemilikan institusional, komposisi dewan komisaris independen, reputasi kantor akuntan publik dan kompensasi bonus terhadap manajemen laba (Studi empiris pada perusahaan finance yang terdaftar di BEI tahun 2008-2011). Jurnal Akuntansi, 2(1), 1-28.

Nouri, Y., \& Abaoub, E. (2014). Accounting manipulations and IFRS: Evidence from French companies. International Journal of Economics and Finance, 6(11), 229.

Nurani, W., \& Dillak, V.J. (2019). Pengaruh profitabilitas, struktur modal, kepemilikan publik dan bonus plan terhadap income smoothing. Jurnal Akuntansi, Audit dan Sistem Informasi Akuntansi, 3(1), 154-168.

Obigbemi, I.F., Omolehinwa, E.O., Mukoro, D.O., Ben-Caleb, E., \& Olusanmi, O.A. (2016). Earnings management and board structure: evidence from Nigeria. Sage Open, 6(3), 1-15.

Palestin, H. S. (2009). Analisis pengaruh struktur kepemilikan, praktik corporate governance dan kompensasi bonus terhadap manajemen laba (Studi empiris pada di PT Bursa Efek Indonesia). (Disertasi). Universitas Diponegoro, Program Pasca Sarjana, Semarang.

Panjaitan, D.K., \& Muslih, M. (2019). Manajemen laba: Ukuran perusahaan, kepemilikan manajerial dan kompensasi bonus. Jurnal ASET (Akuntansi Riset), 11(1), 1-20.

Pappas, K., Walker, M., Xu, L.A., \& Zeng, C. (2020). Do government subsidies 
affect income smoothing? University

of Manchester. https://doi.org/

Available at SSRN: https://ssrn.com/ abstract $=3061933$

Pereira, V. (2015). Managing people in the world's largest commercial employer: an exploratory study on Indian Railways. International Journal of Indian Culture and Business Management, 10(2), 136-156.

Santos Cabalgante, B., Garcia Osma, B., \& Romero, D. (2019). Accounting quality in railway companies during the 19th and 20th centuries: The case of Spanish NORTE and MZA. Accounting and Business Research, Forthcoming, 49(3), 271-304.

Sarkar, J., Sarkar, S., \& Sen, K. (2008). Board of directors and opportunistic earnings management: Evidence from India. Journal of Accounting, Auditing \& Finance, 23(4), 517-551.

Savoldi, A. (2009). Competiton and regulation in the railway industry. (Dissertation). IMT Institute for Advanced Studies, PhD Program in Economics, Markets and Institutions, Italy.

Scholtens, B., \& Kang, F. (2013). Corporate social responsibility and earnings management: Evidence from Asian economies. Corporate Social Responsibility and Environmental Management, 20(2), 95-112.

Schreiner, M. (1997). How to measure the subsidy received by a development finance institution. Economics \& Sociology, 2361.

Shahzad, F., Rauf, S.A., Saeed, A., \& Al Barghouthi, S. (2017). Earning management strategies of leveraged family and non-family controlled firms: An empirical evidence. International Journal of Business \& Society, 18, 503-518.

Shuto, A. (2007). Executive compensation and earnings management: Empirical evidence from Japan. Journal of International Accounting, Auditing and Taxation, 16(1), 1-26.

Simanjuntak, B.H., \& Anugerah, L.A. (2018). Pengaruh kecakapan manajerial, penerapan corporate governance, kompensasi bonus dan leverage terhadap manajemen laba dengan ukuran perusahaan sebagai variabel moderasi (Pada perusahaan manufaktur yang terdaftar di BEI 2015-2017). Jurnal Magister Akuntansi Trisakti, 5(2), 165-184.

Singh, A.K., Aggarwal, A., \& Anand, A.K.
(2017). Corporate governance mechanisms and earnings management in India a study of bselisted companies. Delhi Business Review, 18(1), 43-54.

Sivakumar, K., \& Waymire, G. (2003). Enforceable accounting rules and income measurement by early 20th century railroads. Journal of Accounting Research, 41(2), 397-432.

Soliman, M., \& Ragab, A.A. (2013). Board of director's attributes and earning management: Evidence from Egypt. Proceedings of 6th International Business and Social Sciences Research Conference.

Soliman, W.S. (2019). The Influence of political costs on income smoothing: Evidence from listed Egyptian firms. International Journal of Accounting and Financial Reporting, 9(2), 29-50.

Sriastuti, N. (2015). Kereta api pilihan utama sebagai moda alternatif angkutan umum massal. PADURAKSA: Jurnal Teknik Sipil Universitas Warmadewa, 4(1), 26-34.

Suaryana, A. (2007). Pengaruh komite audit terhadap kualitas laba. Jurnal Ilmiah Akuntansi dan Bisnis, 2(1), 1-22.

Sudibya, S. (2007). Pengembangan restrukturisasi PT Kereta Api (Persero) Divisi Angkutan Perkotaan Jabotabek. (Disertasi). Universitas Diponegoro, Program Pasca Sarjana, Semarang.

Sukmoro, E., Sulistiyono, A., \& Karjoko, L. (2019). Restructuration of Public Service Obligation (PSO), Infrastructure Maintenance and Operation (IMO), Track Access Charge (TAC) on PT. Kereta Api Indonesia (Persero) based on justice. Paper is presented at the 3rd International Conference on Globalization of Law and Local Wisdom (ICGLOW 2019).

Suleiman, M. (2019). Effect of debt covenant violation on accrual-based earnings management of listed consumer goods firms in Nigeria. Paper is presented at the International Conference in Management and Finance.

Sumiyati, S., \& Hartono, J. (2017). Kualitas akrual dan manajemen aktivitas riil seasoned equity offering perusahaan high technology di Asia Pasifik. Global Financial Accounting Journal, 1(1), 88-106.

Tahir, M., Ibrahim, S., \& Nurullah, M. (2019). Getting compensation right-The choice of performance measures in CEO bonus contracts and earnings management. The British Accounting 
Review, 51(2), 148-169.

Ujah, N.U., \& Brusa, J. (2014). Earnings management, financial leverage, and cash flow volatility: An analysis by Industry. Journal of Business and Economics, 5(3), 338-348.

Vakilifard, H., \& Mortazavi, M. S. (2016). The impact of financial leverage on accrual-based and real earnings management. International Journal of Academic Research in Accounting, Finance and Management Sciences, 6 (2), 53-60.

Watts, R.L., \& Zimmerman, J.L. (1978). Towards a positive theory of the determination of accounting standards. Accounting Review, 112134.

Widowati, M. (2013). Pengaruh corporate governance, bonus plan, dan firm size terhadap manajemen laba. Fokus Ekonomi: Jurnal Ilmiah Ekonomi, 8(1).

Wijaya, V.A., \& Christiawan, Y.J. (2014). Pengaruh kompensasi bonus, leverage, dan pajak terhadap earning management pada perusahaan yang terdaftar di bursa efek Indonesia tahun 2009-2013. Tax \& Accounting Review, 4(1), 316.

Wijayana, S., \& Gray, S.J. (2019). Institutional factors and earnings management in the Asia-Pacific: Is IFRS adoption making a difference? Management International Review, 59 (2), 307-334.
Yasser, S., \& Soliman, M. (2018). The effect of audit quality on earnings management in developing countries: The case of Egypt. International Research Journal of Applied Finance, 9(4), 216-231.

Yustiningarti, N.D., \& Asyik, N.F. (2017). Pengaruh asimetri informasi, mekanisme corporate governance dan kompensasi bonus terhadap manajemen laba. Jurnal Ilmu dan Riset Akuntansi (JIRA), 6(9).

Zamri, N., Rahman, R.A., \& Isa, N.S.M. (2013). The impact of leverage on real earnings management. Procedia Economics and Finance, 7, 86-95.

Zhao, Y., Zhou, D., Zhao, K., \& Zhou, P. (2019). Is the squeaky wheel getting the grease? Earnings management and government subsidies. International Review of Economics \& Finance, 63, 297-312.

Zubaidah, S., \& Anwar, A.S.H. (2019). Pengaruh nilai perusahaan, resiko keuangan, kualitas audit, dan kompensasi bonus terhadap earning manajemen (Studi pada perbankan syariah). SNHRP, 265-280.

Zulaecha, H.E., \& Yuli, Y. (2019). Investigasi dampak ukuran perusahaan, kepemilikan manajerial, kompensasi eksekutif dan leverage terhadap earnings management. Jurnal Dinamika UMT, 2(2), 23-32. 